UDC 78.071.1

DOI $10.33287 / 222009$

Bashmakova Natalia, PhD in Arts, the docent, Professor of the „Folk instruments” chair, Dnipropetrovsk Music Academy after Mikhail Glinka тел. (095) 553 - 08 - 93 e-mail: nbashmakova.7@gmail.com

Bakalinska Liliya, Graduate student of the chair „Orchestral instruments” of Dnipropetrovsk Music Academy after Mikhail Glinka тел. (093) 488 - 80 - 58 e-mail: lilplayhard@gmail.com

\title{
„HOMMAGE A PACO” BY FRANK ANGELIS IN THE CONTEXT OF CONTEMPORARY TRENDS OF ACCORDIONAL ART
}

The purpose of this research is to identify the specificity of pop and jazz stylistics as one of the characteristic trends of modern accordion art, using the analysis of the composition „Hommage a Paco” by Frank Angelis. The methods of the proposed scientific article are based on the use of research approaches (genre, style, textual, analytical), which allow to identify the specific embodiment of trends in the current stage of the development of accordion art in the modern repertoire. Scientific novelty. Despite its widespread use in practice, Frank Angelis's composing work has not been subject to scientific understanding; in particular, his work has not been analyzed in detail in contemporary Ukraine. Conclusions. As a result of the analysis of Frank Angelis's „Hommage a Pacco”, it was founded that the specificity of the formation is coordinated by the principle of double-frequency (the first part has an expositional character, the second - jazzimprovisational); the individuality and expressiveness of the aesthetics of the theme are determined by the dances of the famous Spanish virtuoso guitarist Paco de Lucia (Allegres, Bulires and Tangos), which underlie the work. The specificity of the harmonic plan is mainly based on alternate septaccords and noncords, and the thematicism is modified by texturing. The dedication to the creator of the ,new flamenco" style 
is reflected in a diverse palette of playing tools, most of which mimic the specificity of guitar techniques (so the specific accordion tremolo gives the music material an expressive, precise, more sonorous sound - the color of the flamenco, and creates an invoice-like texture). Also in the melodic line are reflected specific guitar techniques, including ,long picado”, „rasgeado”, „alsapua”. A peculiar feature of the composer's style is the use of jazz elements such as: „quasi-improvisation”, „minisolo". Combining music from different directions, F. Angelis created the unique composition, giving it the characteristic features of Spanish flamenco and jazz music.

The key words: jazz music, improvisation, synthesis, style, flamenco.

Башмакова Наталія Вікторівна, кандидат мистецтвознавства, доцент, професор кафедри „Народні інструменти" Дніпропетровської академії музики ім. М. Глінки

Бакалінська Лілія Миколаївна, магістрант кафедри „Оркестрові інструменти” Дніпропетровської академії музики ім. М. Глінки

\section{„Hommage a Расо” Франка Анжеліса в контексті сучасних тенденцій баянно-акордеонного мистецтва}

Мета дослідження - на прикладі аналізу композиції „Ноmmage a Расо” Франка Анжеліса виявити специфіку естрадноджазової стилістики як однієї з характерних тенденцій сучасного баянно-акордеонного мистецтва. Методи пропонованої наукової статті спираються на застосування дослідницьких підходів (жанрових, стильових, текстологічних, аналітичних), які дозволяють виявити специфіку втілення в репертуарі тенденцій сучасного етапу розвитку баянно-акордеонного мистецтва. Наукова новизна. Не дивлячись на широке використання в практиці композицій Ф. Анжеліса, композиторський доробок митця ще й досі не підлягав науковому осмисленню, зокрема в Україні його творчість детально не аналізувалася. Висновки. У результаті аналізу твору „Hommage a Расо” Франка Анжеліса було виявлено, що специфіка формоутворення координується принципом двочастинності (перша частина має експозиційний характер, друга - джазово-імпровізаційний); індивідуальність та виразність естетики тематизму визначають танці відомого іспанського гітариста-віртуоза Пако де Люсії (Allegres, Bulires та Tangos), що 
лежать в основі твору. Специфіка гармонічного плану будується здебільшого на альтерованих септакордах та нонакордах, тематизм видозмінюється за рахунок фактурного викладення. Присвята творцю стилю „нове фламенко” відбивається у різноманітній палітрі засобів гри, більшість з яких імітують специфіку гітарних прийомів (так специфічний акордеонний прийом tremolo придає музичному матеріалу більш виразного, чіткого, дзвінкого звучання - колорит фламенко, а також створює фактурно-динамічний контраст). В мелодичній лінії віддзеркалюються специфічні гітарні техніки, серед яких „тривале пікадо”, „расгеадо”, „альсапуа”. Своєрідною рисою композиторського стилю Ф. Анжеліса $\epsilon$ використання джазових елементів, таких як „quasi-iмпровізація”, „міні-соло”. Поєднавши музику різних напрямків Ф. Анжеліс створив самобутню композицію, наділивши іiі характерними ознаками іспанського фламенку, а також джазу.

Ключові слова: джаз, імпровізація, синтез, стиль, фламенко.

Башмакова Наталья Викторовна, кандидат искусствоведения, доцент, профессор кафедры „Народные инструменты" Днепропетровской академии музыки им. М. Глинки

Бакалинская Лилия Николаевна, магистрант кафедры „Оркестровые инструменты” Днепропетровской академии музыки им. М. Глинки

„Hommage a Расо" Франко Анжелиса в контексте современных тенденций баянно-аккордеонного искусства

Цель исследования - на примере анализа композиции „Hommage a Расо” Франко Анжелиса выявить специфику эстрадноджазовой стилистики как одной из характерных тенденций современного баянно-аккордеонного искусства. Методы достижения поставленной цели опираются на применение исследовательских подходов (жанровых, стилевых, текстологических, аналитических), которые позволяют выявить специфику воплощения в репертуаре тенденций современного этапа развития баянно-аккордеонного искусства. Научная новизна. Несмотря на широкое использование в практике произведений Ф. Анжелиса, композиторское наследие мастера еще не познало научного осмысления, в частности в Украине его творчество подробно не анализировалось. Выводы. В результате анализа произведения „Ноmmage a Расо” Франко Анжелиса было 
обнаружено, что специфика формообразования координируется согласно принципу двучастности (первая часть имеет экспозиционный характер, вторая - джазово-импровизационный); индивидуальность и выразительность эстетики тематизма определяют танцы знаменитого испанского гитариста-виртуоза Пако де Люсии (Allegres, Bulires и Tangos), лежащие в основе произведения. Специфика гармонического плана строится в основном на альтерированных септаккордах и нонаккордах, тематизм видоизменяется за счет фактурного изложения. Посвящение создателю стиля „новое фламенко” отражается в разнообразной палитре средств игры, большинство из которых имитируют специфику гитарных приёмов (так специфический аккордеонный приём tremolo придаёт музыкальному материалу более выразительного, четкого, звонкого звучания - колорит фламенко, и создаёт фактурно-динамический контраст). Также в мелодической линии отражаются специфические гитарные техники, среди которых „длительное пикад”, „расгеадо”, „альсапуа". Своеобразной чертой композиторского стиля Ф. Анжелиса является использование джазовых элементов, таких как „quasi-импровизация”, „мини-соло”. Соединив музыку различных направлений Ф. Анжелис создал самобытную композицию, наделив её характерными признаками испанского фламенко, а также джаза.

Ключевые слова: джаз, импровизация, синтез, стиль, фламенко.

Setting of the problem. In the modern academic repertoire of accordion art, there is a well-established tendency to gravitate towards pop and jazz styles, which is embodied as in the composer's dimension (R. Würtner, A. Haydenko, E. Derbenko, V. Zubitsky, Y. Oleksiv, P. Stashev, A. Stashev Frosini et al.), as well as in performing arts (S. Grinchenko, J. Gonzales, P. Dranga, Y. Kobayashi, V. Kovtun, V. Murza, Y. Purits, etc.). Artists - such as: A. Van Damm, V. Vlasov, R. Galliano, F. Morocco, B. Mironchuk, O. Na Yun Kin, O. Sklyarov and etc. - combine the data of the sphere of activity ness. The role of a kind of popularizer, the spread of this trend is played by competitive international practice. For example, in such competitions as Trophee Mondiale, Castelfidardo, Montrond les Bains, Coupe Mondiale, the nomination (represented by high, quantitative figures), in which the 
accordion is presented in a variety jazz style, is very popular. And in this context, the practical response is the work of the famous French accordion-composer F. Angelis.

Topicality of this exploration is due to the fact that the process of expanding the original accordion repertoire is subordinated to the idea of genre-style synthesis and from the same positions is of scientific interest tested by the work of creativity of Frank Angelis, who through the prism of accordion art combines the basics of jazz culture and Spanish music in creation „Hommage a Paco".

The literature review. The dissertative works of Marina Bulda [1] and Yuri Dyachenko [2] are devoted to revealing the role and place of pop and jazz music in the evolution of accordion art. Musicologists, in the context of the performance of domestic and foreign accordionists, consider the stylistic directions of pop and jazz music and reveal the dynamics of development of the original repertoire claim that the process of its enrichment goes through the synthesis of different styles. As analytical music material in the mentioned studies, attention is paid to the works of R. Galliano, A. Beloshitsky, A. Van Dammou, V. Vlasov, R. Wurtner, V. Gridin, G. Deira, F. Morocco, V. Podgorny, A. Piazzolli, A. Fossen. Consequently, in this context, the work of Frank Angelis still remains outside the scope of domestic scientists.

The purpose of the study is to analyze the specificity of pop and jazz stylistics as one of the characteristic tendencies of the modern trends of accordion art, using the analysis of the composition „Hommage a Paco” by Frank Angelis.

The object of the research is jazz pop music in modern accordion mastery and the subject is the specificity of embodying the jazz trends of the accordion mastery in the composition of Frank Angelis's „Hommage a Paco”.

Presenting main material. Before presenting the results of an analysis of one of Frank Angelis' well-known work, „Hommage a Paco”, briefly outlines the genre landmarks of this contemporary French composer. Among the genres he tried were works of great form, it should be emphasized that sonatas and suites („Impasse”, „Brel-Bach”, „Haïti”), as well as many concert miniatures (from the most famous „Nocturne”, „Toccata”, „Amalgam”). Characteristic features of the composer style of Frank Angelis (who by the way is actively involved in performing and teaching activities) are: the use of jazz elements (,,quasi- 
improvisations", „mini-solos"), the use of tonal matching of the same textured layers and support for Latin American music.

These features are clearly embodied in the composition „Hommage a Paco", which was created in 2006 and is dedicated to the legendary Spanish virtuoso guitarist, creator of the „new flamenco” style Paco de Lucia.

Dynamic (Allegro tempo is indicated) and large-scale composition (287 cycles, average sound time -4.20 minutes), does not obey to the strict canons of formation, and reflects the improvisational thinking of F. Angelis. The free sound flow in the ,quasi-improvised" constructions is about one third of the work, in which there is spontaneity and intensity of development (the theme seems to be 'released' from the established framework).

The specificity of the formation of the play „Hommage a Paco” is coordinated by the principle of two-part - the first has an expositional character, the second - jazz-improvisational. It can be schematically depicted as:

\begin{tabular}{|c|c|c|c|c|c|c|c|c|c|c|c|c|c|c|c|c|c|c|c|c|c|c|c|c|}
\hline \multicolumn{6}{|c|}{ A } & $\rightarrow$ & \multicolumn{2}{|c|}{ B } & \multicolumn{8}{|c|}{$\mathbf{A}_{\mathbf{1}}$} & $\rightarrow$ & \multicolumn{5}{|c|}{$\mathbf{B}_{1}$} & \multicolumn{2}{|c|}{ Кода } \\
\hline \multicolumn{2}{|c|}{$\mathbf{a}$} & \multicolumn{2}{|c|}{ б } & \multicolumn{2}{|c|}{$a_{1}$} & \multirow[b]{2}{*}{ 4T. } & \multirow{2}{*}{$\begin{array}{c}\text { c } \\
16 \mathrm{r} .\end{array}$} & \multirow{2}{*}{$\frac{c_{1}}{16 r}$} & \multicolumn{2}{|c|}{$\sigma_{1}$} & \multicolumn{2}{|c|}{$\sigma_{2}$} & \multicolumn{2}{|c|}{$a_{2}$} & \multicolumn{2}{|c|}{63} & \multirow[b]{2}{*}{ 4T. } & \multirow{2}{*}{$\begin{array}{c}c_{2} \\
16 \mathrm{r} .\end{array}$} & \multirow{2}{*}{$\begin{array}{c}\mathbf{c}_{3} \\
16 \mathrm{r} .\end{array}$} & \multicolumn{2}{|c|}{$\sigma_{4}$} & 65 & \multicolumn{2}{|c|}{$a_{3}$} \\
\hline $15 \mathrm{r}$. & $15 \mathrm{~T}$ & $8 \mathrm{r}$. & 7т. & $1 \mathrm{ST}$ & $15 \mathrm{~T}$ & & & & $8 \mathrm{r}$ & רT & $15 \mathrm{r}$. & $15 \mathrm{r}$ & 8r. & 1т. & 8r. & $8 \mathrm{r}$ & & & & 8r. & 8r. & \begin{tabular}{l|l} 
8r. & 1
\end{tabular} & 8r. & $12 \mathrm{r}$ \\
\hline$F$ & $\mathrm{~F}$ & B & C & C & $\mathrm{F}$ & F & . & & B & C & c & & C & F & B & $\mathrm{C}$ & As & $\mathrm{c}-\mathrm{m}$ & & As & B & g-moll & & \\
\hline
\end{tabular}

The first theme (presented in a simple three-part form) is a decisive, clear, affirmative, based on a rhythmic compass. In it from the first beat sound in the register ,tutti” dissonant chords, the use of which is inherent in flamenco music, while in the guitar tradition, they are performed reception rasgeado (1-6 vols.). To simulate it in the accordion reading the technique of the game - tremolo bellows (which performs the first chords of each phrase) is used. The same technique achieves a dynamic nuance - $\mathrm{f}$ and ensures the articulation of the initial element of the theme (emphasis in combination with the staccato). The sub-rhythm of the first theme indicates the 8 clock frequency $(\mathrm{a}, \mathrm{a} 1)$ containing the sequence of alternation of the following clock sizes: $3 / 8,2 / 8,5 / 8,4 / 8,3$ 
/ 8,2 / 8, 8 / 8, 4/8. Such metric instability (emphasized by the author's tres rythme trailer) conveys an image of sharpness, unrestrainedness and unpredictability.

In the middle period of the first theme, described metro-rhythmic formula is kept, which is now emphasized by the right-hand party. Thus laid out in the bass melodic line, provides a greater integrity (compared to its extreme sections) and active, moving character. The theme sounds in the party of the left hand, with its sound reminiscent of the double bass solo in the ensemble. It is based on eight note durations on a previous combination of alternation of intonation accents followed by patchy notes, emphasizing the syncopated rhythm. The composer seems to imitate the sound of a guitar in the technique alsapua (alzapua), which uses the thumb of the right hand, acting as a mediator. The reprisal period of the first theme is structurally and tonally consistent with the source material. The middle element of the phrase (,mini-solo”), which is set out in sixteenth durations, transforming by dynamics movement.

The second theme (in the form of a simple two-part, containing exposition conduct and „quasi-improvisation”) is significantly different in character from the first - rigid, choppy statements are replaced by light narrative phrases that are built on a stable meter (stroke size 8/8). The ease of sounding the melodic material is ensured by the tessiturregister decision - the accompanying voices do not go beyond the small octave, the melodic material is laid out in the registers "risolo" and „unison”. In the first place is the rhythm that is characteristic of Latin American music. Free but concentrated and upward and downward imitating-improvisational phrases give a sense of flight, desire for change, and alterations give excitement and indecision to their implementation. The second theme contains such a technique as rehearsals, which embodies a characteristic of the guitar technique of sound-making, called „long-range picado" - a game with frequent changes of the index and middle fingers (4t., 8t., 12t.).

In the second part of the composition - jazz-improvisational, there is a development of thematic material - in fact, it is the improvisation prescribed by the composer, containing a number of dynamic, textural, tonal and timbre (register) comparisons.

Initially, the middle period material of the first theme sounds, which is modified by the specific reception of the game - tremolo (every eighth note in the bass is performed). This enhances the dynamic contrast with the previous section. In the next section of the 
improvisation, Frank Angelis seems to create an intonation of France, which is embodied through „broad" chromatic „wave-like” constructions (,quasi-improvisations"), and the specified register „bayan with bassoon" gives the sound of softness and tenderness that is not specific to flamenco music.

So sixteenth notes, which are „strung” on a frame of eight notes in the bass-theme, create an imitation of the guitar strings that return the theme flamenco color. The sixteenth notes act as a spring, preparing the listener for the final climax of the piece. Performing this section requires a performer of a high level of technical skill, because the increase in the rate of movement of the right hand is complicated by uncomfortable octave jumps. Also, when creating an interpretive version of the work, the artist should pay attention to the fact that the dynamic nuances are almost not prescribed by the author, but their absence is partially offset by such remarks as: „Tres rythme”, „Crescendo poco a poco”, „Tres leger”, „Plus fort”, „Brillant”.

The code is based on the material of the first theme. Using the „tutti” register and the basic basses combined with the optional system, the author amplifies the dynamic voltage. The composition ends with a fff dissonant chord (g-moll), which (like the initial one) is performed by tremolo reception, but its rhythmic organization becomes more decisive - not eight but sixteenth durations.

Combining the characteristic features of Spanish flamenco and jazz, Frank Angelis created a unique composition, which today is a real masterpiece of the jazz variety of modern accordion music. In 2013, this work was awarded the UNESCO Prize (according to the information of the International Confederation of Accordionists).

Conclusions. As a result of the analysis of Frank Angelis's „Hommage a Pacco", it was founded that the specificity of the formation is coordinated by the principle of double-frequency (the first part has an expositional character, the second - jazz-improvisational); the individuality and expressiveness of the aesthetics of the theme are determined by the dances of the famous Spanish virtuoso guitarist Paco de Lucia (Allegres, Bulires and Tangos), which underlie the work.

The specificity of the harmonic plan is mainly based on alternate septaccords and noncords, and the thematicism is modified by texturing. The dedication to the creator of the „new flamenco" style is reflected in a diverse palette of playing tools, most of which mimic the specificity of guitar techniques (so the specific accordion tremolo gives the music material an expressive, precise, more sonorous sound - the color of the flamenco, and creates an invoice-like texture). Also in the melodic line 
are reflected specific guitar techniques, including „long picado”, „rasgeado", „alsapua”. A peculiar feature of the composer's style is the use of jazz elements such as: „quasi-improvisation”, „mini-solo”. Combining music from different directions, F. Angelis created a unique composition, giving it the characteristic features of Spanish flamenco and jazz.

The prospects of the study can be viewed in two directions: complementing other musical works by F. Angelis, revealing similar principles in the accordion creativity of modern domestic and foreign composers.

\section{Список використаних джерел і література:}

1. Булда М.В. Естрадно-джазова музика в акордеонно-баянному мистецтві України другої половини XX - початку XXI ст.: композиторська творчість і виконавство : автореф. дис. на здобуття наук. ступеня канд. мистецтвознавства : 17.00.03. Харків, 2007. 19 с.

2. Дяченко Ю.С. Естрадно-джазовий напрям баянно-акордеонного мистецтва XX - початку XXI ст.: композиторські та виконавські виміри : автореф. дис. на здобуття наук. ступеня канд. мистецтвознавства : 17.00.03. Харків, 2017. 19 с.

3. Структура музыки фламенко. URL: https://sites.google.com/site/flamenko101/home (дата звернення: 12.03.2019).

4. Травин А. Биография Пако де Люсия (Paco De Lucia). URL: http://worldelectricguitar.ru/musician/Paco_De_Lucia (дата звернення: 19.04.2019).

5. Frank Angelis - French accordionist and composer. URL: http://www.musicforaccordion.com/inform/afranck (дата звернення: 21.05.2019).

\section{References:}

1. Bulda, M.V. (2007). Pop and jazz music in accordion art of Ukraine from the second half of the XX - the beginning of the XXI centuries: composer creativeness and performance. Extended abstract of candidate's thesis. Kharkiv [in Ukrainian].

2. Djachenko, Ju.S. (2017). Pop and jazz directions of accordion art of the XX the beginning of the XXI centuries: composer and performing scopes. Extended abstract of candidate's thesis. Kharkiv [in Ukrainian].

3. The flamenco music structure. Retrieved from https://sites.google.com/site/flamenko101/home [in Russian].

4. Travin, A. (2019). Biography Paco de Lucia. Retrieved from http://worldelectricguitar.ru/musician/Paco_De_Lucia [in Russian].

5. Frank Angelis - French accordionist and composer. URL: http://www.musicforaccordion.com/inform/afranck [in English]. 